\title{
Ladybird Coccinella septempunctata (Coleoptera: Coccinellidae) prefers toxic prey in laboratory choice experiment
}

\author{
OLDŘICH NEDVĚD ${ }^{1,2}$ and SARA SALVUCCI ${ }^{3}$ \\ ${ }^{1}$ Faculty of Science, University of South Bohemia \\ ${ }^{2}$ Institute of Entomology, Biology Centre, Branišovská 31, CZ370 05 České Budějovice, Czech Republic; e-mail: nedved@prf.jcu.cz \\ ${ }^{3}$ Department of Agricultural and Environmental Science, University of Perugia, Perugia, Italy
}

Key words. Coccinellidae, Coccinella septempunctata, Harmonia axyridis, aphid, Aphis sambuci, elder, Sambucus nigra, food specificity, prey preference, food choice, optimal foraging, toxicity

\begin{abstract}
In a laboratory experiment, we investigated the preference of larvae and adults of Coccinella septempunctata (Coleoptera: Coccinellidae) for three aphid species: two essential prey, Acyrthosiphon pisum and Aphis philadelphi, and a toxic prey Aphis sambuci. Surprisingly, the toxic aphid was consumed at twice the rate of the two essential prey species. The stages and genders of the ladybirds did not differ in their preference for aphid species. In the tritrophic interaction, in the field, on the elder host plant Sambucus nigra, A. sambuci is usually avoided by $C$. septempunctata. To measure ladybird preference, apterous females of the three selected aphid species were released in a Petri dish followed by a ladybird. After four hours, we removed the ladybird, counted the number of aphids of each species that survived, and calculated the number of aphids of each species consumed in total. We examined preference by considering separately the first two aphids consumed by a predator (early feeding), and all remaining aphids consumed thereafter (late feeding). The consumption rates of the first two individuals did not deviate from expected values with no preference; i.e., ladybirds fed on aphids without choice in the beginning of experiment when they were hungry. The ladybirds did express preference thereafter, but our hypothesis that the ladybirds should be able to distinguish among the aphids during later phase of the experiment and choose the most profitable species, or at least distinguish between essential and toxic prey, was rejected .
\end{abstract}

\section{INTRODUCTION}

Hodek (1962, 1973) distinguished several types of prey for aphidophagous ladybirds. One such division was suitable vs. unsuitable prey. Suitable prey could function either as essential, enabling larval development and egg production, or as alternative, enabling just survival or accumulation of energetic reserves for overwintering (Hodek, 1996). Unsuitable prey, which can include toxic species, can be either rejected or accepted. This classification arose from the finding that several aphid species were accepted but unsuitable, i.e. they were inadequate for larval development or oviposition. Michaud (2005) stressed that the suitability of prey sometimes differed for larval development and adult reproduction and proposed a more detailed classification based on these differences.

Hodek (1956) found a low feeding rate of the most common European ladybird Coccinella septempunctata on elder aphid Aphis sambuci. Larvae did not complete their development and eventually died during the 3rd or 4th instar. In England, however, half the individuals of C. septempunctata that fed on A. sambuci survived to become adults, although of very small size (Blackman, 1965).

Freshly emerged ladybird adults reared as larvae on essential prey species died after 2-3 weeks when subsequently fed only with $A$. sambuci. Overwintered adults fed before diapause with another prey were not affected (Hodek, 1957b). Hodek (1957a) showed that the mortality resulted from toxicity, rather than as the effect of low feeding rate (consistently fewer than 20 aphids per day in comparison to 50-150 suitable aphids). The cause of low feeding rate on $A$. sambuci was not explained, although "little attraction" was mentioned.

The target aphid, A. sambuci, feeds on elder Sambucus nigra, which contains toxic compounds (D'Abrosca et al., 2001), and the aphid probably sequesters these compounds in its body. One of the toxins is cyanoglycoside sambunigrin, producing hydrocyanate after enzymatic splitting. Potential enzymes were identified in C. septempunctata (Kuznetsov, 1948). Another potentially toxic compound is alkaloid sambucine (Auster \& Schafer, 1956).

In natural conditions, $C$. septempunctata avoids feeding on $A$. sambuci, except during the early season after overwintering, and does not lay eggs on S. nigra (Hodek, 1957b). Other ladybird species such as Adalia bipunctata often develop on this prey (Nedvěd, 1999), although at a slower rate than on more suitable aphid species (Hodek, 1957a). Several aphids have been found to be toxic for some ladybirds, either causing gradual poisoning (e.g. A. sambuci), or an acute toxic effect (e.g. Aphis nerii feeding on Nerius oleander) (Iperti, 1966).

Complex tritrophic ecological relationships between host plant-aphid-predator have been the subject of several investigations. Lists of suitable / essential prey species would be better replaced by lists of host complexes (Nedvěd, 1999). Different host plants may differ in their nutritional qualities for a given aphid species, which in turn affects the development of ladybirds consuming the 
aphid (e.g. alfalfa vs. faba bean - Acyrthosiphon pisum C. septempunctata; Giles et al., 2002). There are also cases when different host plants are infested by different races or cryptic species of aphids (Aphis fabae complex; Gauffre \& D'Acier, 2006). Host plants may also provide olfactory and visual stimuli recognised by predators in the field, which may be missing in laboratory experiments and thus affect the choice of particular prey (Ninkovic et al., 2001; Zhu \& Park, 2005).

Many experiments measuring the suitability (e.g. assessed as consumption rate, duration of development, and resulting adult weight) of several prey species for ladybirds have been conducted (for C. septempunctata by Hauge et al., 1998; Kalushkov \& Hodek, 2004; for older studies, see summary table in Hodek, 1996). The design of those experiments, however, included only one prey species offered to one predator species (nonetheless, these experiments were sometimes described as preference studies). Choice / preference among several prey species offered simultaneously has been studied rarely. Some of the feeding preference experiments used two very different types of prey [e.g. the spirea aphid, Aphis citricola, and the twospotted spider mite, Tetranychus urticae (Lucas et al., 1997); Aphis gossypii and conspecific (ladybird) eggs (Omkar et al., 2006)]. The preference for aphids Aphis pomi over caterpillars of Choristoneura rosaceana was confirmed for $C$. septempunctata and Harmonia axyridis (Lucas et al., 2004). C. septempunctata females more readily attacked aphids (Acyrthosiphon pisum) than weevil (Hypera postica) larvae (Evans et al., 2004).

True food preference studies - behavioural selection between several food types - are best performed by cafeteria experiments, as has been done for several insect taxa. In this type of experiment, equal (surplus) numbers or amounts of several food types are offered to an animal for a standard time period, and the number of prey items (or amount of food) consumed is then determined. Easily studied are preferences of herbivores (e.g. caterpillars; Dorn et al., 2001), and granivores (e.g. ground beetles; Honěk et al., 2005, 2006). Multichoice (cafeteria) experiments with insect predators are more difficult and thus less frequent.

Blackman (1967) found that larvae of the ladybird Adalia bipunctata preferred the more suitable aphid, Myzus persicae, over Aphis fabae, but they could not avoid feeding on the toxic Megoura viciae mixed with suitable Acyrthosiphon pisum, and eventually died. Larvae of $C$. septempunctata ate even more $M$. viciae than $A$. pisum. The quality of mixed diets depended on the quality of the constituent aphid species (Nielsen et al. 2002). Larvae of $C$. septempunctata that were given pure toxic $A$. sambuci and a mixed $\operatorname{diet}$ of $A$. sambuci and suitable $M$. persicae died within 18 days and none of the larvae developed to fourth instar. The predation rate of the polyphagous bug Macrolophus pygmaeus was higher on the aphid Myzus persicae than on Macrosiphum euphorbiae when offered simultaneously (Lykouressis et al., 2007). H. axyridis preferred the most suitable Myzus persicae over Aphis fabae (Soares et al., 2004).

We hypothesized that aphidophagous predators such as C. septempunctata might recognize particular prey items as suitable or toxic even if they were separated from the host plant. The objective of this study was to quantify the preference/rejection of suitable vs. toxic aphid species in a laboratory small cafeteria experiment, where individual ladybirds could choose among three aphid species.

\section{MATERIAL AND METHODS}

We collected adult ladybirds (C. septempunctata) in March at an overwintering site near České Budějovice, South Bohemia, Czech Republic (square grid KFME: 7051; coordinates: $48^{\circ} 55^{\prime} \mathrm{N}, 14^{\circ} 19^{\prime} \mathrm{E}$ ). We kept them in a refrigerator (about $6^{\circ} \mathrm{C}$ ). Some individuals were separated into pairs, kept in Petri dishes (9 $\mathrm{cm}$ diameter), and provided with filter paper (folded accordion-style), and a small vial with water. They were placed in an incubator at $25^{\circ} \mathrm{C}$ and $18 \mathrm{~L}: 6 \mathrm{D}$. These pairs were fed ad libitum with living aphids Acyrthosiphon pisum reared on young Vicia faba plants.

Egg clutches produced by these pairs were transferred daily into similar Petri dishes. Larvae after hatching were fed also with $A$. pisum. They were used for the experiment as mid fourth instars. We assumed balanced sex ratio among the larvae, since there were no signs of presence of male killing agents, i.e. almost all larvae hatched from eggs (cf. Majerus, 2006). A second group of adults was transferred one week before the experiment from cold storage to rearing conditions as mentioned above. Both these adults and larvae were deprived of food one day prior to the experiment.

The small cafeteria experiment was set up in Petri dishes ( $9 \mathrm{~cm}$ diameter) with a $3 \times 3 \mathrm{~cm}$ piece of wet cellulose. The walls of the lower dish were painted with polytetrafluorethylene, making them quite smooth and thereby preventing aphids from crawling onto the upper dish. The small cafeteria experimental design (three prey species) was used instead of a more typical large cafeteria design (many prey types) for the following reasons: because the consumption rates of the ladybirds were low, either (a) few aphids of each species might be eaten during the experiment if many aphid species were available, making statistical analyses problematic, or (b) the experiment would need to be much longer if run with large cafeteria design, in which case many aphids would die during the experiment and would have to be replaced, whereas others would be born and would have to be removed regularly.

Ten wingless adult females of each of three species of aphids were gently transferred from their host plant to each Petri dish. Aphis sambuci were obtained from twigs of their host plant, elder Sambucus nigra. Aphis philadelphi was selected as a congeneric species with $A$. sambuci, similar in size $(3 \mathrm{~mm})$ and appearance and collected from the ornamental shrub sweet mockorange Philadelphus coronarius. Acyrthosiphon pisum grown on faba bean $V$. faba was included as a control, since it was used as prey for both larvae and adults before experiment, and as a reference species for comparison with other small cafeteria experiments that we have run (Salvucci et al., unpubl.). A. pisum is larger $(4 \mathrm{~mm})$ and possesses much longer legs than the other two species. Experiments were run from late May to early June, a period when adults and larvae of C. septempunctata were abundant on many wild plants.

One ladybird (male, female or larva) was added to each experimental Petri dish about $30 \mathrm{~min}$ after aphids were released. The experiments were conducted at $25^{\circ} \mathrm{C}$ and under natural illumination enforced with a fluorescent lamp $(11 \mathrm{~W}, 40 \mathrm{~cm}$ above 
dishes). The experiments were run around mid-day, when ladybirds have high and stable consumption rates (Nakamuta, 1987). C. septempunctata feed around mid-day, while thermoregulative basking was regularly observed during cool mornings (Honěk, 1985).

We observed the behaviour of each ladybird until it consumed two aphids. The species identity of the first and second aphid eaten was recorded for "early feeding". Ladybirds then continued to feed on other aphids ("late feeding"). We checked the dishes each hour, and removed dead aphids and neonates. When five individuals of a particular aphid species were eaten or had died we replaced them with new aphids regularly distributed throughout the dish to ensure that many aphids were available for choice. After four hours, we removed the ladybird, counted the number of remaining aphids of each species and calculated the number of aphids eaten. Each of a total of 40 ladybirds was used only once.

We used repeated measures ANOVA (repeated 3 prey species for each individual predator) to analyse effects of the three aphid species and of stage and sex of predator (larva, male, female) on the number of prey consumed. In the analysis of early feeding, we used non-transformed data (there were only 0 , 1 , or 2 prey consumed, and such numbers are not suitable for logarithmic transformation). Numbers of aphids eaten during the second phase of experiment (late feeding) were likely to follow Poisson or lognormal distribution. To improve the normality and homoscerascity of numbers of aphids, we applied $\log (x+1)$ transformation, which at the same time transformed multiplicativity to additivity, which is important for observing interactions between factors in repeated measures ANOVA (Zar, 1999). Medians of consumption rates were also tested using Friedman ANOVA.

\section{RESULTS}

Average numbers of aphids of each species eaten during the first phase of experiments (early feeding, Table 1) were slightly different from the expected value in the absence of choice ( 0.67 , i.e. two aphids out of three species eaten by each ladybird). Stage and sex of ladybirds had no effect on the choice, since the interaction between stage/sex and aphid species in repeated measures ANOVA was non-significant $(\mathrm{F}=0.74, \mathrm{p}=0.57)$. There was a weak selection (choice) between the three aphids ( $\mathrm{F}$ $=3.3, \mathrm{p}=0.04$ ), although Tukey HSD test between aphid species showed no preference, i.e. no significant difference between any pair of species out of the three. During the early feeding, there was no indication of prey rejection, but in some instances, the prey escaped.

TABLE 1. Consumption rates of individuals (adults and larvae pooled) of $C$. septempunctata on three aphid species. Numbers of aphids eaten per ladybird $(\mathrm{N}=40)$ during four hours.

\begin{tabular}{l|ccc}
\hline & $\begin{array}{c}\text { Early feeding } \\
\text { Mean } \pm \text { S.D. }\end{array}$ & $\begin{array}{c}\text { Late feeding } \\
\text { Mean } \pm \text { S.D. }\end{array}$ & Median \\
\hline A. pisum & $0.40 \pm 0.59 \mathrm{a}$ & $1.38 \pm 1.35 \mathrm{a}$ & 1.0 \\
A. philadelphi & $0.80 \pm 0.76 \mathrm{a}$ & $1.73 \pm 1.32 \mathrm{a}$ & 1.5 \\
A. sambuci & $0.80 \pm 0.72 \mathrm{a}$ & $2.68 \pm 1.56 \mathrm{~b}$ & 3.0 \\
\hline
\end{tabular}

Lowercase letters indicate significant differences on $5 \%$ level. Early feeding $=$ two first prey items consumed in the beginning of experiment, when ladybird was hungry; late feeding $=$ all other prey items.

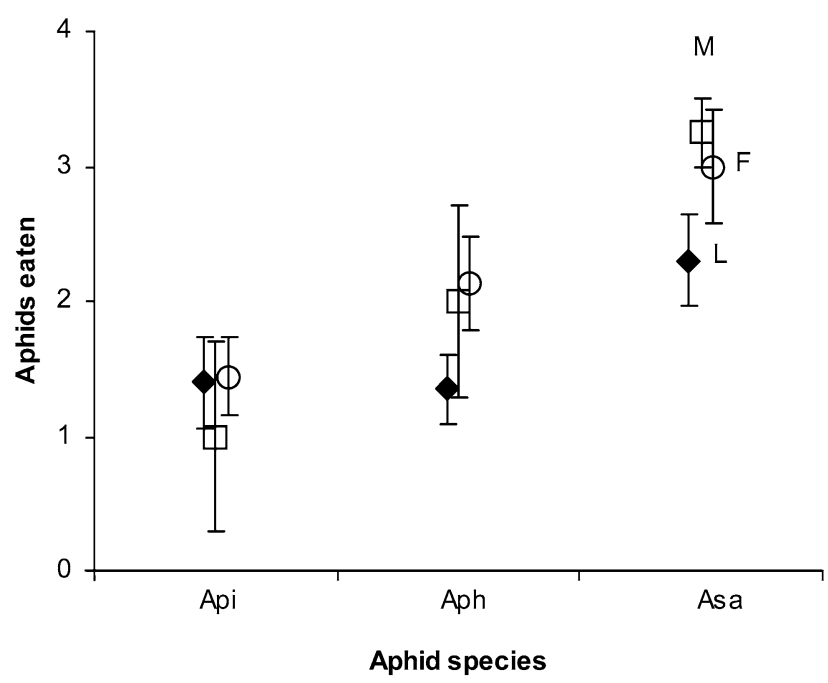

Fig. 1. Consumption rates per $4 \mathrm{~h}$ of $C$. septempunctata larvae ( $\mathrm{L}$ - solid diamonds), males ( $\mathrm{M}$ - open squares), and females ( $\mathrm{F}$ - open circles) on three aphid species. Api = Acyrthosiphon pisum, Aph $=$ Aphis philadelphi, Asa $=$ Aphis sambuci. . Bars $=$ standard errors of means.

During late feeding, there was no significant difference in average consumption rate between the stages/sexes ( $\mathrm{F}$ $=1.45, \mathrm{p}=0.25)$ - larvae were only slightly less voracious than adults, and females slightly more than males. However, there was a strong choice for the aphid species $(\mathrm{F}=8.3, \mathrm{p}=0.00055)$ revealed by ANOVA. Rates of consumption of A.pisum and A. philadelphi were similar, and both were less than the rate of consumption of A. sambuci (Table 1). This difference was also found between medians of consumption rates (Friedman ANOVA $\chi^{2}(\mathrm{~N}=40, \mathrm{df}=2)=13.5, \mathrm{p}=0.001$. Tukey HSD test between aphid species showed a significant difference of consumption rate of $A$. sambuci and that of other two species; $A$. pisum was eaten less than $A$. philadelphi, but non-significantly. There was no interaction $(\mathrm{F}$ $=0.65, \mathrm{p}=0.63$ ) between the two predictors (aphid species $\mathrm{x}$ stage/sex) - larvae, males, and females showed the same type of choice (Fig. 1).

\section{DISCUSSION}

It was hypothesized that selection would result in animals that tend to hunt for their prey efficiently. Such is the case for $H$. axyridis fed with Myzus persicae and Aphis fabae (Soares et al., 2004). Under a mixed diet regime, feeding rate gradually increased with the proportion of $M$. persicae. Relative growth rate was not affected, while fecundity and fertility increased. Our finding that $C$. septempunctata selects unsuitable prey, however, is contradictory to optimal foraging theory.

We expected that the two first prey items eaten (during early feeding) would be chosen randomly, without any preference for aphid species, because starved ladybirds should not miss any chance to feed. We found that fewer individuals of the control species $A$. pisum were consumed in comparison to the two Aphis species, but the difference was not significant. 
When only the first prey item consumed is considered, there is still slight selection against $A$. pisum. This species has longer legs than the two Aphis species, and may escape an attack more often by walking or kicking. The dropping behavior that is typical of $A$. pisum (e.g. $73 \%$ of individuals dropped from the host plant in presence of C. septempunctata in the study of Losey \& Denno, 1998), could not be effective on the bottom of our Petri dishes. We do not think that active ladybird choice occurs in early feeding. No choice behaviour was found during similar small cafeteria experiments between A. pisum as standard and other aphid species (Salvucci et al., unpubl.). Handling (i.e., consumption) time was not measured precisely in our experiments, but it seemed to be longer (up to $5 \mathrm{~min}$ ) for larger $A$. pisum with long legs than for the two smaller species (as short as $2 \mathrm{~min}$ ). But the total consumption time of all items represented a small part of the total time of the experiment, and thus any differences in consumption time between prey species contributed little if anything to ladybird preference/rejection as measured here.

The mean consumption rate (adults and larvae pooled) was 7.8 aphids per ladybird per four hours, which would result in 47 aphids per $24 \mathrm{~h}$ if ladybirds continued to feed at such a rate for an entire day. In fact, they do no not feed so much at night, and our ladybirds were starved for a day prior the experiment. C. septempunctata ate about 7 adult aphids Schizaphis graminum per hour in both laboratory and field (McConnell \& Kring, 1990). They ate either 105 aphids Macrosiphum avenae (Ghanim et al., 1984) or 116 such aphids (Wetzel et al., 1982) per day. Sinha et al. (1982) reported a strong functional response of larvae of $C$. septempunctata to varying density of Lipaphis erysimi, that resulted in a range of 33-349 aphids consumed (or at least damaged) per day. The low feeding rates observed in our experiment may have resulted from the slight toxic effect of consumed $A$. sambuci, as suggested by the low feeding rate ( 20 aphids per day) observed by Hodek (1956) on pure diet of $A$. sambuci.

There were small differences in feeding rate between the stages/sexes. More importantly, larvae, males, and females had the same patterns of choice. We used postdiapause, preoviposition adults to minimize variability in feeding rate. Although supplied with the same amount of food, reproducing ladybirds gradually decreased their feeding rate with increasing age (Dixon \& Agarwala, 2002).

We are not able to fully explain the preference of C. septempunctata for the toxic prey $A$. sambuci over two very suitable prey species $A$. pisum and $A$. philadelphi. C. septempunctata regularly reproduced on A. philadelphi in the field (Nedvěd, 1999), while Adalia bipunctata suffered high larval mortality on "Aphis fabae" from $P$. coronarius (Kalushkov, 1998). The discrepancy between avoidance of $A$. sambuci in the field (Hodek, $1957 \mathrm{~b}$ ) and acceptance in laboratory may be attributable to the lack of warning signals associated with the host plant, $S$. nigra. Ladybirds may simply avoid searching for food on plants that produce particular volatiles. In other cases, the plant volatiles may attract aphid predators. The smell of accumulated honeydew of different aphids, which was missing in our experiments, may also be selected by predators (Havelka \& Syrovátka, 1991), instead of the sensory stimuli provided by the aphids themselves.

During the experiment, we did not observe ill health of ladybirds caused by the toxins ingested with $A$. sambuci. Instead, we observed only somewhat lower feeding rate. In previous experiments, the larvae died (Hodek, 1956) or $50 \%$ developed to much smaller adults (Blackman, 1965) only after exclusive ingestion of this aphid species. We confirmed in rearing experiments (unpublished data) that larvae of $C$. septempunctata fed from hatching (on May 25 and May 30) exclusively with $A$. sambuci, died during the fourth instar after a long period of low rate feeding. Hodek (1956) suggested seasonal differences in the chemical (nutritional) composition of $A$. sambuci (in experiments started on June 24, death occured in or before 4th instar, in experiments initiated July 22, death occured in or before 3rd instar). Earlier (May) rearing did not yield better survival.

The toxin was probably acquired by the aphids from the host plant. In a similar experiment, slower development rate and higher mortality was recorded in the ladybird $H$. axyridis when fed on the aphid Aulacorthum magnoliae on elder, Sambucus sieboldiana, than when fed on this aphid from potato, Solanum tuberosum (Fukunaga \& Akimoto, 2007). The aphids evidently absorb toxic substances or their precursors from elder (as noted in the Introduction). However, in another experiment (inpublished data), $H$. axyridis larvae performed well in feeding on $A$. sambuci reared on $S$. nigra, resulting in normal adults.

The amount of toxin in our experiment was diluted by the volume of other prey consumed, and the action of toxins, if any, may be delayed beyond the four hours of observation in the present experiment. While leaves of $S$. nigra were always present with the aphids in Hodek's (1956) experiments, searching ladybirds in our trials had no warning signal (volatiles from host plant or problems with digestion/regurgitation) to avoid the toxic prey. The toxins may also have been broken down by the aphids when they were removed from the plant and placed in the Petri dish.

Although these proposed mechanisms can explain a lack of avoidance of the unsuitable prey, the active preference for A. sambuci observed here requires some additional explanation. We speculate that these aphids may differ in size, physical structure, behaviour and/or their own chemical defence (not acquired from plant) from congeneric species, so as to make them preferred prey under our experimental conditions.

Our experimental design in fact measured ladybird preferences (reaction to visual, olfactory and taste stimuli) as well as aphid defence (except for dropping down). Physical structure such as cuticle stiffness, length of appendages and overall body size may affect acceptance 
of particular prey by ladybirds. However, the two Aphis species were of equal size, and the larger $A$. pisum should be preferred by the large predator $C$. septempunctata according to the hypothesized relationship between predator and prey body size of Dixon \& Hemptinne (2001). But this hypothesis was not empirically supported within guilds of aphidophagous ladybirds (Dixon, 2007), and is also contradicted by our experiments.

As evolution has proceeded, toxic $A$. sambuci may have lost escape behaviour (walking away, kicking) or ability to produce and discharge defensive secretion from abdominal cornicles. Prey mobility, included in escape behaviour as a defensive mechanism, was found to be important for prey selection in $H$. axyridis provided with aphid Hyaliodes vitripennis and spider mite Tetranychus urticae (Provost et al., 2006). The role of defensive secretions from aphid cornicles has been reviewed by Pasteels (2007).

Such losses (of defensive behaviour or secretion) would not be penalised by natural selection because the aphids are still sufficiently protected by the host plant and its compounds in natural conditions. The escape behaviour and defensive secretion of $A$. sambuci remain to be compared with congeneric species.

ACKNOWLEDGEMENT: We thank J. Havelka for advice on aphid rearing. The project was supported by the grant number MSM 6007665801.

\section{REFERENCES}

Auster F. \& Schafer J. 1956: Arzneipflanzen (7. Lieferung), Veb Georg Thieme, Leipzig.

BlackMAN R.L. 1965: Studies on specificity in Coccinellidae. Ann. Appl. Biol. 56: 336-338.

Blackman R.L. 1967: Selection of aphid prey by Adalia bipunctata L. and Coccinella 7-punctata L. Ann. Appl. Biol. 59: 331-338.

D’Abrosca B., DellaGreca M., Fiorentino A., Monaco P., Previtera L., Simonet A.M. \& Zarrelli A. 2001: Potential allelochemicals from Sambucus nigra. Phytochemistry 58: 1073-1081.

Dixon A.F.G. 2007: Body size and resource partitioning in ladybirds. Popul. Ecol. 49: 45-50.

Dixon A.F.G. \& Agarwala B.K. 2002: Triangular fecundity function and ageing in ladybird beetles. Ecol. Entomol. 27: 433-440.

Dixon A.F.G. \& Hemptinne J.L. 2001: Body size distribution in predatory ladybird beetles reflects that of their prey. Ecology 82: $1847-1856$.

Dorn N.J., Cronin G. \& Lodge D.M. 2001: Feeding preferences and performance of an aquatic lepidopteran on macrophytes: plant hosts as food and habitat. Oecologia 128: 406-415.

Evans E.W., Richards D.R. \& Kalaskar A. 2004: Using food for different purposes: female responses to prey in the predator Coccinella septempunctata L. (Coleoptera: Coccinellidae). Ecol. Entomol. 29: 27-34.

Fukunaga Y. \& Акімото S. 2007: Toxicity of the aphid Aulacorthum magnoliae to the predator Harmonia axyridis (Coleoptera: Coccinellidae) and genetic variance in the assimilation of the toxic aphids in H. axyridis larvae. Entomol. Sci. 10: $45-53$.

Gauffre B. \& D'Acier A.C. 2006: New polymorphic microsatellite loci, cross-species amplification and PCR multiplexing in the black aphid, Aphis fabae Scopoli. Mol. Ecol. Notes 6: $440-442$.

Ghanim A.E., Freier B. \& Wetzel T. 1984: Studies on the occurrence of cereal aphids and their predators in one winterwheat field in the Mansoura region (Arab Republic of Egypt). Arch. Phytopathol. Plant Prot. 20: 261-267.

Giles K.L., Madden R.D., Stockland R., Payton M.E. \& DillWITH J.W. 2002: Host plants affect predator fitness via the nutritional value of herbivore prey: Investigation of a plantaphid-ladybeetle system. BioControl 47: 1-21.

Hauge M.S., Nielsen F.H. \& Toft S. 1998: The influence of three cereal aphid species and mixed diet on larval survival, development and adult weight of Coccinella septempunctata. Entomol. Exp. Appl. 89: 319-322.

HaVelKa J. \& SyrovÁtKa O. 1991: Stimulatory effect of the honeydew of several aphid species on the females of gall midge Aphidoletes aphidimyza (Rondani) (Dip., Cecidomyiidae) - Electroantennograph studies. J. Appl. Entomol. 112: 341-344.

HoDeK I. 1956: The influence of Aphis sambuci L. as prey for the ladybird beetle Coccinella septempunctata L. V̌̌st. Čs. Spol. Zool. 20: 62-74 [in Czech, Engl. abstr.].

Hodek I. 1957a: The influence of Aphis sambuci L. as food for Coccinella 7-punctata L. II Čas. Čs. Spol. Entomol. 54: 10-17 [in Czech, Engl. abstr.].

Hodek I. 1957b: The larval food consumption of Coccinella 7-punctata L. Zool. Listy 6: 3-11 [in Czech, Engl. abstr.].

Hodek I. 1962: Essential and alternative food in insects. In Strouhal H. \& Beier M. (eds): Transactions of the XIth International Congress of Entomology (Wien 1960). Vol. 2. pp. 697-699.

Hodek I. 1973: Biology of Coccinellidae. Academia, Praha, 260 pp.

Hodek I. 1996: Food relationships. In Hodek I. \& Honěk A. (eds): Ecology of Coccinellidae. Kluwer Academic Publishers, Dordrecht, pp. 143-238.

HoNĚK A. 1985: Activity and predation of Coccinella septempunctata adults in the field (Col., Coccinellidae). J. Appl. Entomol. 100: 399-409.

HonĚK A., MartínKová Z. \& SASKa P. 2005: Post-dispersal predation of Taraxacum officinale (dandelion) seed. J. Ecol. 93: 345-352.

HonĚK A., SASKa P. \& MARTínKovÁ Z. 2006: Seasonal variation in seed predation by adult carabid beetles. Entomol. Exp. Appl. 118: 157-162.

IPERTI G. 1966: Comportement naturel des Coccinelles aphidiphages du Sud-Est de la France: Leur type de spécificité, leur action prédatrice sur Aphis fabae L. Entomophaga 11: 203-210.

KalushKov P. 1998: Ten aphid species (Sternorrhyncha: Aphididae) as prey for Adalia bipunctata (Coleoptera: Coccinellidae). Eur. J. Entomol. 95: 343-349.

Kalushrov P. \& Hodek I. 2004: The effects of thirteen species of aphids on some life history parameters of the ladybird Coccinella septempunctata. BioControl 49: 21-32.

KuzNetsov N.YA. 1948: Principles of Insect Physiology. Vol. 1. Izd. Akad. Nauk SSSR. 380 pp. [in Russian].

Losey J.E. \& DenNo R.F. 1998. Interspecific variation in the escape responses of aphids: Effect on risk of predation from foliar-foraging and ground-foraging predators. Oecologia 115: 245-252.

Lucas E., Coderre D. \& Vincent C. 1997: Voracity and feeding preferences of two aphidophagous coccinellids on Aphis citricola and Tetranychus urticae. Entomol. Exp. Appl. 85: 151-159. 
Lucas E., Demougeot S., Vincent C. \& Coderre D. 2004: Predation upon the oblique-banded leafroller, Choristoneura rosaceana (Lepidoptera: Tortricidae), by two aphidophagous coccinellids (Coleoptera: Coccinellidae) in the presence and absence of aphids. Eur. J. Entomol. 101: 37-41.

Lykouressis D.P., Perdikis D.C. \& Gaspari M.D. 2007: Prey preference and biomass consumption of Macrolophus pygmaeus (Hemiptera: Miridae) fed Myzus persicae and Macrosiphum euphorbiae (Hemiptera: Aphididae). Eur. J. Entomol. 104: 199-204.

MAJERus M.E.N. 2006: The impact of male-killing bacteria on the evolution of aphidophagous coccinellids. Eur. J. Entomol. 103: $1-7$.

McConnell J.A. \& KRING T.J. 1990: Predation and dislodgement of Schizaphis graminum (Homoptera, Aphididae), by adult Coccinella septempunctata (Coleoptera, Coccinellidae). Environ. Entomol. 19: 1798-1802.

Michaud J.P. 2005: On the assessment of prey suitability in aphidophagous Coccinellidae. Eur. J. Entomol. 102: 385-390.

NAKAMUTA K. 1987: Diel rhythmicity of prey-search activity and its predominance over starvation in the lady beetle, Coccinella septempunctata bruckii. Physiol. Entomol. 12: 91-98.

NEDVĚD O. 1999: Host complexes in predaceous ladybeetles (Col., Coccinellidae). J. Appl. Entomol. 123: 73-76.

Nielsen F.H., Hauge M.S. \& Toft S. 2002: The influence of mixed aphid diets on larval performance of Coccinella septempunctata (Col., Coccinellidae). J. Appl. Entomol. 126: 194-197.

Ninkovic V., Al Abassi S. \& Pettersson J. 2001: The influence of aphid-induced plant volatiles on ladybird beetle searching behavior. Biol. Control 21: 191-195.
OMKar, Pervez A. \& Gupta A.K. 2006: Why do neonates of aphidophagous ladybird beetles preferentially consume conspecific eggs in presence of aphids? Biocontrol Sci. Tech. 16: 233-243.

Pasteels J.M. 2007: Chemical defence, offence and alliance in ants-aphids-ladybirds relationships. Popul. Ecol. 49: 5-14.

Provost C., Lucas E., Coderre D. \& Chouinard G. 2006: Prey selection by the lady beetle Harmonia axyridis: The influence of prey mobility and prey species. J. Insect Behav. 19: 265-277.

Sinha T.B, Pandey R.K., Singh R., Tripathi C.P.M. \& Kumar A. 1982: The functional response of Coccinella septempunctata Linn., a coccinellid predator of mustard aphid, Lipaphis erysimi Kalt. Entomon 7: 7-10.

Soares A.O., Coderre D. \& Schanderl H. 2004: Dietary selfselection behaviour by the adults of the aphidophagous ladybeetle Harmonia axyridis (Coleoptera: Coccinellidae). $J$. Anim. Ecol. 73: 478-486.

Wetzel T., Ghanim A.E. \& Freier B. 1982: Zur Nahrungsaufnahme von Coccinella septempunctata L. bei optimalem Angebot von Aphiden der Art Macrosiphum avenae (Fabr.). Arch. Phytopathol. Plant Prot. 18: 89-96.

ZAR J.H. 1999: Biostatistical Analysis. 4th ed. Prentice Hall, Upper Saddle River, NJ, 931 pp.

ZhU J.W. \& PARK K.C. 2005: Methyl salicylate, a soybean aphid-induced plant volatile attractive to the predator Coccinella septempunctata. J. Chem. Ecol. 31: 1733-1746.

Received September 30, 2007; revised and accepted January 21, 2008 